\title{
Our Neighbors Observe and We Explain: Moses Mendelssohn's Critical Encounter with Edmund Burke's Aesthetics
}

\author{
Tom Furniss \\ University of Strathclyde
}

In 1987, Frederick C. Beiser wrote that "it is a sad legacy of our nonhistorical age that Moses Mendelssohn is now remembered only as the philosopher 'refuted' by Kant in the 'Paralogismus' chapter of the first Kritik. This is no reputation for a thinker who was called 'the Socrates of his age,' and who was regarded as the leading light of the Aufklärung in Berlin." ${ }^{1} Y e t$ if Mendelssohn no longer features in the philosophical canon, he is far from being a neglected figure in the English-speaking world. ${ }^{2}$ Several recent writers have focused on Mendelssohn's location within the Enlightenment, particularly stressing his sustained commitment to Leibniz-Wolffian metaphysical rationalism. ${ }^{3}$ Yet what is especially interesting about Mendelssohn is that, as Beiser suggests, he was "the last" and "the most modern of all the rationalists because he was aware of, and responded to, "the crisis of metaphysics'" that developed in the third quarter of the eighteenth century as metaphysics came under attack from "the skepticism of Hume and the French philosophes; the empiricism of Crucius's and Locke's followers in Germany; and the whole hoard of Popularphilosophen, who simply had no time for rationalistic Gründlichkeit." ${ }^{4}$ As his Philosophical Dialogues (1755) demonstrates, Mendelssohn was concerned from his first publication onwards with defending Leibniz's and Wolff's systems against the assaults of French critics such as Voltaire, Pierre Bayle, Prémontval, and Maupertuis. ${ }^{5}$ What was particularly challenging to Mendelssohn was that the "enemies" were already occupying the Berlin Academy, the main accomplishment of which, according to Lewis White Beck, "was to feed into German intellectual life new ideas from France and England"; by the mid-eighteenth century, he suggests, "the Academy was almost evenly divided between the partisans of Newton and of Leibniz and Wolff." ${ }^{\prime 6}$ It should nonetheless be recognized that Mendelssohn, like some of the popular philosophers he is sometimes associated with, was also 
"open to the influx of new ideas, particularly from the English empiricists."7 Robert E. Norton points out that "although Mendelssohn felt most comfortable with the theoretical apparatus he had inherited from Leibniz and Wolff, he had also devoted himself to a careful and sympathetic study of the principal works of the major English philosophers, above all those of Locke, Shaftesbury, and Hutcheson." 8 Indeed, as we will see, what is particularly fascinating about Mendelssohn is his attempt to use elements of British empiricism to bolster Leibniz-Wolffian metaphysics in face of the crisis that had been brought about by British and especially French empiricist materialism. Equally fascinating is the fact that Mendelssohn repeatedly found that British philosophy would not translate (in a double sense) into German or into the Leibniz-Wolffian system that he saw as Germany's characteristic philosophical achievement. Norton notes, for example, that "in the early 1760s . . . Mendelssohn had been busy trying to translate Shaftesbury's works, but soon abandoned the project. 'My translation has been stuck for a few weeks now,' he complained in a letter to Thomas Abbt on 22 February 1762. 'The Lord is an obstinate Englishman who frequently refuses to accept a German coat.' "'9

In this article I want to focus on a series of essays on aesthetics that Mendelssohn published between 1755 and 1761 and later included in his Philosophische Schriften of 1761. Paul Guyer argues that Mendelssohn's theory of art "can be regarded as the culmination of the rationalist tradition in aesthetics grounded upon Leibnizo-Wolffian foundations by Alexander Gottlieb Baumgarten."10 For Beck, the aesthetic theory that emerges in these articles "was Mendelssohn's most important contribution to philosophy" in that they take "several steps . . . in the direction from Baumgarten to Kant." ${ }^{11}$ But my concern with Mendelssohn's aesthetic writings is less to do with their role in the evolution of German aesthetic theory than with investigating how they can be read as one of his earliest responses to the looming crisis in metaphysics. As we will see, Mendelssohn's aesthetic writings both draw on and resist the aesthetic ideas of a number of British and French authors. Writers such as Shaftesbury and Hutcheson are generally amenable to him because they were committed to the equation between aesthetics and ethics that was epitomized in the notion of the "beautiful soul."12 My central concern, however, is with Mendelssohn's response to the first edition of Edmund Burke's Philosophical Enquiry into the Origin of our Ideas of the Sublime and Beautiful of 1757, a text that was much more challenging to Mendelssohn partly because it broke that equation between aesthetics and ethics.

No one, to my knowledge, has undertaken a systematic investigation of Mendelssohn's response to Burke's Enquiry. ${ }^{13}$ Yet this response is of interest for a number of reasons. First, it is an important part of the general story of Burke's reception in Europe. ${ }^{14}$ Secondly, it is a revealing episode in the encounter between British empiricist aesthetics and German rationalist metaphysics of the Leibniz-Wolffian school. Mendelssohn's attempt to subsume Burke's aesthetics 
under his version of that metaphysics exposed the incommensurable relationship between two aesthetic discourses or paradigms and precipitated a crisis in Mendelssohn's own theory. ${ }^{15}$ Mendelssohn's attempt to deal with that crisis resulted in a series of creative elaborations and modifications of his own LeibnizWolffian aesthetic theory that ultimately failed to absorb or cope with Burke's Enquiry. Tracing the intricacies of Mendelssohn's engagement with Burke will nonetheless help me to indicate that "failed" influence may be as important and revealing as "successful" influence in the transmission and transformation of ideas between writers and between national cultures.

Burke's aesthetic theory entered Germany via a number of independent routes. Johann Georg Hamann, for example, seems to have encountered the Enquiry while he was in London in 1757 and later cited it in his review of Kant's Beobachtungen über das Gefühl des Schönen und Erhabenen. ${ }^{16}$ But in this essay I want to concentrate on the role that Mendelssohn and Lessing played in introducing Burke's Enquiry into Germany and on the impact it made on their own aesthetic theories. In the introduction to a recent German translation of Burke's Enquiry, Werner Strube suggests that "the impact of Burke's aesthetics [in Germany] is not so much as an influence but more as a stimulation. Many aesthetic theorists spark off Burke, and they use his aesthetics as a contrasting foil to outline their own position more clearly."17 Strube identifies two main patterns in the German reception of Burke's Enquiry: almost all German readers of Burke in the second half of the eighteenth century praise his empirical observations about aesthetic effects while simultaneously finding his theoretical account of those effects inadequate; and most German aesthetic thinkers-though Kant was a prominent exception-were troubled by the way Burke defined and celebrated the sublime as the polar opposite of the beautiful and continued, instead, to regard the beautiful as the main object of enquiry. ${ }^{18}$ The templates for these responses were established by Mendelssohn and Lessing. As we will see, Mendelssohn "sparked off" the Enquiry and sought to use Burke's empiricist aesthetics as a contrasting foil to outline his own metaphysical theories more clearly. Indeed, Mendelssohn's critical encounter with Burke's aesthetics, and especially his account of the sublime, can be seen to have precipitated the creative flourishing of Mendelssohn's own aesthetic thought. At the same time, however, this encounter can also be read as threatening the very foundations of Mendelssohn's aesthetic theory and as bringing the development of that theory to an abrupt end.

\section{LESSING PASSES ON THE ENQUIRY}

The anonymous first edition of Burke's Enquiry was published in London in April 1757. In the same month, Lessing and Mendelssohn, along with Friedrich Nicholai, launched a new journal of aesthetics-the Bibliothek der schönen Wissenschaften und der freyen Künste..$^{19}$ In November 1757, Lessing wrote to Nicholai 
announcing that he had received a new English work on the beautiful and the sublime and that he would send it to Mendelssohn to review for the Bibliothek as soon as he had finished reading it. ${ }^{20}$ In January 1758, he wrote to Mendelssohn to say that, out of idleness and boredom, he had begun to translate the Enquiry and looked forward to discussing it with him. ${ }^{21}$ In February, Lessing misleadingly reported that he had almost finished the translation and that he would send it to Mendelssohn as soon as it was printed. In the same letter he makes the following comments about the Enquiry:

As you will find, it contains some very good comments, although the whole building is not much use. The author says: all of our passions divide themselves into two main branches; passions that are concerned with self-preservation, and passions that lead to social life. The first, because their objects are pain and danger, are the source of the sublime; the second, which are based in love, are the source of the beautiful. What do you say to this system? That the author must have a very peculiar concept of the soul. And he does. For him, the passions have been put into the soul by God; they are not something that arises out of the essence of the soul, out of a certain kind of representations, but something that God has added to the soul's essence. A lot of sentiments, he says, arise simply out of the mechanical structure of the body, out of the natural form and composition of the soul, and not at all from sequences of representations and conclusions of the soul... But even if the author's basic principles are not much use, his book is tremendously useful as a collection of all the observations and perceptions that the philosopher who would undertake the same study must accept as indisputable. He has assembled all the materials for a good system that no one knows better than you how to use.22

In these remarks, Lessing establishes one of the main paradigms for the German reception of the Enquiry. Burke has assembled an unparalleled set of empirical observations of aesthetic effects, but he is unable to make proper use of such material because of an inadequate theory of the "soul." Instead of grounding aesthetic experience in the essence of the human soul-which, for Lessing, is its "Wolffian power of making representations" ${ }^{23}$ - Burke argues that aesthetic feelings "arise simply out of the mechanical structure of the body, out of the natural form and composition of the soul," and that the capacity for aesthetic experience is something that God has added to the soul for pragmatic endsthat is, to ensure human beings' self-preservation and self-reproduction. More specifically, Lessing's suggestion that Mendelssohn is the best person to transform Burke's empirical materials into a proper theoretical system is based on the fact that Mendelssohn had already published a number of essays that examine aesthetic questions from a metaphysical viewpoint influenced by Leibniz, Wolff, and Baumgarten. Furthermore, Lessing is passing on the responsibility of dealing with the Enquiry to Mendelssohn in a way that Mendelssohn will later try to do to Lessing. 
In April 1758, indeed, Lessing sent his copy of the Enquiry to Mendelssohn, admitting that his translation project had stalled. ${ }^{24}$ Despite Mendelssohn's ongoing encouragement, Lessing never completed his translation. ${ }^{25}$ Nor did he complete his "Bemerkungen über Burkes Philosophische Untersuchungen über den Ursprung unserer Begriffe vom Erhabenen und Schönen," a manuscript fragment probably written in 1758 or 1759 but unpublished in Lessing's lifetime. ${ }^{26}$ Rather than engaging with Burke's aesthetics, the "Bemerkungen" consists of a short series of remarks that tend to side-step Burke's arguments altogether, articulating instead what Lessing took to be the given "truths" of aesthetic theory. Similarly, in his major published work on aesthetic theorythe Laocoön of 1766-Lessing completely ignores Burke. James T. Boulton suggests that this omission indicates that "Lessing considered the Enquiry as mainly confirming his own views," but an attentive reading of Laocoön reveals that its grounding assumptions are quite different from Burke's. ${ }^{27}$ Burke's basic distinction of aesthetic affect into the sublime and the beautiful is completely ignored in Lessing's almost single-minded focus on the beautiful, while Lessing's groundbreaking account of the distinctive nature and effects of painting and poetry proceeds in apparent ignorance of Burke's equally groundbreaking, but significantly different, discussion of those differences in the final section of the Enquiry. All this suggests not that Lessing considered the Enquiry as confirming his own views, but that Lessing either lost interest in Burke's aesthetics after his early (admittedly ambivalent) enthusiasm, ${ }^{28}$ or that he was simply unable to accept or accommodate a set of empirical observations that he had once thought essential to the aesthetic philosopher.

\section{MENDELSSOHN'S PRE-BURKEAN AESTHETIC THEORY}

Mendelssohn's responses to Burke are importantly different to Lessing's, partly because they appeared in published works that had a tangible impact on later German writers, and partly because Mendelssohn's aesthetic writings are shaped by a real attempt to come to terms with the Enquiry. But in order to measure Burke's impact on Mendelssohn it will be useful to examine the latter's pre-Burkean aesthetic writings. Between 1757 and 1758 Mendelssohn published twenty-one articles on aesthetic subjects in the Bibliothek. ${ }^{29}$ But his most important pre-Burkean publication on aesthetics was Briefe über die Empfindungen (1755).

Commentators often assume that "On Sentiments" presents a single, coherent argument that reflects Mendelssohn's commitment to the Leibniz-Wolffian philosophical system and its extension into aesthetics in Baumgarten's Aesthetica $(1750,1758)$. Such readings tend to pay little attention to the aesthetic form of "On Sentiments"-i.e., that it is a philosophical dialogue, a genre in which Mendelssohn excelled and about which he gave a lot of thought. ${ }^{30}$ In what follows, I will suggest that although "On Sentiments" strives to be the kind of 
Socratic dialogue in which the central character simply voices the arguments of the "German Socrates," it actually stages a real philosophical debate that Mendelssohn was having with himself in the late 1750s in which he entertains arguments against Leibniz-Wolffian metaphysics that both attract and repel him.

The immediate model for "On Sentiments" is not Plato but Shaftesbury's The Moralists, a Philosophical Rhapsody (1709), which begins with a prefatory letter from Philocles to Palemon and then reports, in a second letter, a dialogue between Philocles and Theocles in which the latter successfully persuades the former that "beauty and good are ... the same." 31 There are several similarities between The Moralists and "On Sentiments." "On Sentiments" is a dialogue between two main characters (and one minor character) in a series of fifteen letters, together with a preface, conclusion, and endnotes written by a fictional "editor" (who is often equated with Mendelssohn himself). In the first edition, the two main characters are called Palemon and Euphranor; in the second edition, Mendelssohn changed Palemon's name to Theocles, perhaps in order to point up similarities with Shaftesbury's character of the same name. There are therefore four different "voices" in the dialogue, and any attempt to identify the text's aesthetic theory needs to take this into account and also needs to recognize that both Theocles and Euphranor modify their arguments in the course of responding to one another and yet fail to reach an agreement about some of the central differences between them. Yet although Euphranor is made to articulate views that genuinely challenge Theocles, and although Theocles is forced to modify and develop his ideas in the face of Euphranor's challenges, there is textual evidence to support those critics (such as Altmann) who equate Theocles's views with Mendelssohn's. As we will see, for example, the "editor" endorses Theocles's arguments and even supplements them in the conclusion and endnotes. Nonetheless, I want to suggest that there are important ways in which "On Sentiments" reveals that neither Theocles nor the "editor" is able fully to neutralize Euphranor's aesthetic speculations or absorb them into a Leibniz-Wolffian framework.

A key feature of the fictional preface to "On Sentiments" is the way it foregrounds both the relationship between philosophy and national identity and the crisis in metaphysics that Mendelssohn was so concerned about:

Theocles, an English philosopher who inherited the name of that dear enthusiast known to us from the Earl of Shaftesbury's The Moralists, had left his homeland some time ago. The mixture of seductive imagination and French frivolity, peddled as metaphysics by so many of his countrymen, was so starkly at odds with his proclivity for rigor and fundamentals that he made the decision to renounce his fatherland, his tranquility, and his friends' embrace in order to search for a people that treasures accurate thinking more than free thinking. Germany seemed to him to hold out the promise of such a people. He read the immortal writings with which our countrymen have enriched the world in the past century, and people say that 
the soberness, indeed, the very dullness for which they are reproached by some petty critics, was one of the things that drove him to become acquainted with this nation. $^{32}$

But having gone into exile in Germany, the last bastion of true philosophy, Theocles "is supposed to have been more than a little astonished . . . by the specious and careless manner of our present philosophers. He apparently wrote his friends back in England that his hopes were betrayed and that even in Germany the philosophical dilettante had gotten the upper hand."33 Euphranor, a young man of the nobility, is said to be one of the few philosophers in Berlin who is completely suited to Theocles's tastes. ${ }^{34}$ Yet Euphranor is one of those Germans who have been at least partly seduced by the Epicurean ideas of the French and English and he fundamentally disagrees with Theocles's aesthetic theories. Theocles's task, then, is to win back Euphranor to the German metaphysics of the Leibniz-Wolffian school. It is therefore especially interesting that elements of Euphranor's aesthetic theory appear to anticipate Burke's. In other words, before he read Burke, Mendelssohn's aesthetic theory was already in dialogue with aesthetic ideas that Burke would soon articulate in powerful ways.

In his first letter, Euphranor's Epicureanism is revealed in his attempt to dissuade Theocles from producing a rational analysis of the sources of aesthetic pleasure. Yet while his account of the non-rational nature of beauty and its effects-epitomized by the erotic impact of a beautiful woman on a male observer-is quite Burkean, Euphranor is not merely a forerunner of Burke. ${ }^{35}$ In his second letter he tries to forestall Theocles by appearing to invoke Baumgarten's definition of the beautiful: "We would be unhappy if all our sentiments were all at once elucidated and made into clear and distinct representations. Beauty rests, in the opinion of every philosopher, on the indistinct representation of a perfection." ${ }^{36}$ Euphranor's aesthetic theory, then, is similar to that of Johann Georg Sulzer, whose Recherches sur l'origine des sentiments agréables et desagréables (1753-54) combined Baumgarten's theory of sensuous cognition of perfection with "a theory of the subjective delight (Vergnügen) in this sensuous cognition." ${ }^{37}$ This similarity allows Altmann to see "On Sentiments" as an answer to Sulzer's aesthetic theory. ${ }^{38}$ Yet there are also further parallels with the aesthetic theory that Burke would soon publish. The contrast between distinct and indistinct representations (or ideas) might be thought to anticipate the polar opposition in Burke's Enquiry between a clear idea and an aesthetically affecting idea, although the suggestion that the object that is being perceived or represented needs to be perfect is quite un-Burkean. ${ }^{39}$ Yet Euphranor's "youthful ethics" are problematic in several ways, including the fact that he misrepresents Baumgarten's aesthetic theory, in which the experience of beauty is produced by the senses' clear but indistinct representation of a perfection. ${ }^{40}$

When Theocles begins to respond to Euphranor it quickly becomes apparent that his aesthetic theory is based on a very different set of assumptions from 
those that Mendelssohn would shortly encounter in Burke's Enquiry. While Theocles concedes, in his first letter to Euphranor, that "it is a well-established truth that no distinct concept is compatible with the feeling of beauty," he also corrects Euphranor's misrepresentation of Baumgarten by adding that "the expansively clearer the representation of a beautiful object, the more ardent the pleasure that springs from it." 41 Theocles's assertion that pleasure in the beautiful is generated by the clear representation of an indistinct object is an attempt to fend off the possibility that aesthetic experience involves irrationality or depends on the limitations of the human senses or the human mind. In the same vein, he goes on to argue that the soul is capable of experiencing a higher form of intellectual beauty that is grounded in the soul's "positive powers . . . and not in its incapacity, not in the limitation of these original powers." 42 Theocles's assumptions about the positive powers of the soul are grounded on a priori assumptions about the perfect nature of God, and the relative perfection of the human soul created in God's image, drawn from Leibniz and Wolff. For Theocles, it is axiomatic that "the inclination to perfection must be a property of all thinking entities and of God himself to the supreme degree." 43 In human beings, the inclination to perfection is manifested in the soul's delight in its own capacity to generate perfect representations-the Leibniz-Wolffian term for ideas or images. ${ }^{44}$ The highest beauty, for Theocles, originates in this capacity, not (as Burke would attempt to argue) in the mechanical effects of objects on the body's senses and nerves. ${ }^{45}$

In the sixth letter, Theocles reveals that his aesthetic theory is articulated in face of personal anxieties about the threat to genuine philosophy posed by the Epicurean tendency current in France and England that rejects reason and its higher pleasures in favor of frivolous sensuous desires. ${ }^{46}$ Theocles is especially concerned about this tendency because he had himself once fallen under its sway and been almost "completely ruined" by the "doubts about the existence of God and the blessedness of virtue" that it induces. Theocles was saved, he attests, by true philosophy:

\footnotetext{
Thanks be to those true guides who have guided me back to true knowledge and to virtue. Thanks to you, Locke and Wolff! To you, immortal Leibniz! . . Without your help I would have been lost forever. . . . In my solitary hours I implored your immortal writings for help, writings which remain to this day unread by the wider world, and it was they which steered me on the sure path to genuine philosophy, to knowledge of my very self and my origin. ${ }^{47}$
}

That saving knowledge of the self includes the recognition of the soul's "propensity," shared with all thinking beings and "in a certain sense with God," for a "completeness and perfection" that entails "a yearning for concepts that are grounded in one another" - a propensity that is quite distinct from the "sordid desires" that can beset the body.48 (Although Theocles names Locke 
as one of his saviors, there is little sign of Locke's influence in his metaphysical theories.)

Despite receiving this confession from his friend, Euphranor responds in the eighth letter with what he takes to be a challenge to Theocles's whole system. For Euphranor, again anticipating Burke, the rapture produced by the sensuous pleasures of wine and women involves

neither a multitude of concepts nor proportions nor even relations to some common final purpose. . . If this, however, is the case, then your entire edifice falls apart. For did you not say that the sensuous or intellectual perfection of a thing is the reason why we would find pleasure in the entertainment of it?-These examples prove the opposite. The pleasure which certain objects afford us is the reason why we call them "perfect" or "complete."

In an endnote, the "editor" claims that Theocles goes on to refute this fundamental attack on his position, yet the letters themselves do not bear this out. ${ }^{50}$ Instead, Theocles appears to give ground to Euphranor by trying to develop some sort of compromise between those who "have presented our soul as the sole subject of all pleasure" (Leibniz and Wolff presumably) and those who claim that "the source of all pleasure lies in the body." ${ }^{51}$ While insisting that there are intellectual and spiritual pleasures that arise independently of the body, Theocles seeks to investigate what "soul and body have in common such that both can be causes of pleasure." ${ }^{2} 2$ Theocles seems therefore to be attempting to develop an aesthetic theory that takes account of the empirical claims of the bodily materialists while subsuming these claims to his version of the Leibniz-Wolffian philosophy. In having him do so, as several commentators have suggested, Mendelssohn develops a far richer account of aesthetics than Leibniz or Wolff might have produced and thus adds to the enrichment of the Leibniz-Wolffian system introduced by Baumgarten's venture into aesthetics. ${ }^{53}$

In developing his account of the interplay between the pleasures of the body and the pleasures of the soul, Theocles has recourse to a theory that both overlaps with, and significantly differs from, the one that Burke would soon publish. Drawing on anatomical descriptions of the body's system of nerves, such as those in Santorio Santorio's De statica medicina (1725), together with Leibniz's speculations about the medical value of a harmonious bodily tone, Theocles suggests that the sensual enjoyment of the beautiful is produced by, and produces, a wholesome tension and harmonious tone "that furthers the human body's activity and is conducive to its survival."54 (Burke would soon distinguish between the sublime and the beautiful on the basis that the sublime is produced by, or produces, a health-giving tension of the nerves while the beautiful has the effect of relaxing the nerves in a way that poses a threat to the body's well being. ${ }^{55}$ ) Theocles then attempts to reconcile this physiological account of the origins and effects of the beautiful with his a priori theory that 
aesthetic affect arises from the soul's power of generating representations of a perfect object:

Call, now, upon the observer of your bodily actions, call upon the soul. How will it behave? It will become aware of what condition is more comfortable for its true spouse, its body, the condition, namely, that seems to promise the body a longer life and a more active and effective reality. But the soul will never be able to oversee distinctly and lucidly the astonishing intermingling of vessels and their diverse tensions. From within, it will feel an improvement, a transition to a perfection, but it will grasp only in an obscure way how this improvement arose. Put all this together: it will arrive at an indistinct but lively representation of the perfection of its body; reason enough, according to our theory, to explain the origin of a pleasure. ${ }^{56}$

In note (h) the "editor" indicates that Theocles here is echoing Descartes's account, in article 94 of his Les passions de l'âme (1649), of the close interrelation of body and soul during pleasurable experience. ${ }^{57}$ Yet Theocles's suggestion that the soul, in its Cartesian relationship to the body, derives its own kind of aesthetic pleasure from producing "an indistinct but lively representation of the perfection of its body" in the moment of its enjoying physical beauty seems like an unconvincing compromise between the physical and metaphysical aesthetic theories he is attempting to reconcile. Even Theocles recognizes that this account of aesthetic response does not enable a distinction to be made between wholesome and dangerous objects of pleasure. While all sensuous pleasures produce the feeling of an improved state of the body, some of those pleasures can eventually result in bodily and moral harm (only reason can make judgments about the long-term effects of pleasure). Theocles's first attempt to subsume Euphranor's Epicurean claims about aesthetic response under his own transcendental aesthetic theory thus ends up by re-emphasizing the dangers of a bodily aesthetics.

Two letters later Theocles develops a different theoretical compromise between metaphysical and physiological aesthetics by suggesting that aesthetic experience involves a two-way interaction between soul and body facilitated by the brain. He begins by reiterating his claim that "each sensuous rapture, each improved condition of the state of our body, fills the soul with the sensuous representation of a perfection." ${ }^{158}$ A similar process is said to take place in the reverse direction: "every sensuous representation [of a perfection, produced by the soul] must also, in turn, bring with it some well-being of the body, a kind of sensuous rapture." 59 While these claims seem to imply that the soul might in some instances be subject to the body (and vice versa), the following paragraph introduces the brain into the equation in a way that initially looks even more materialist (and Burkean). In one direction, "sensuous rapture begins in the parts of the body by virtue of the effects of external objects and extends from there to the brain" ${ }^{60}$; in the other direction, 
The emotion . . . arises in the brain itself. The representation of a spiritual perfection, the memory of some previously enjoyed sensuous gratification, and the imagination ... arrange the fibers of the brain into an appropriate tone. ... The brain communicates this harmonious tension to the nerves of the other parts of the body and ... the human being acquires a pleasant emotion. ${ }^{61}$

These suggestions might appear to relinquish the theory of the transcendental soul in favor of an aesthetic theory based solely on a materialist account of the interaction between brain and body. In other words, Theocles could be read as having adopted something like a Burkean aesthetic theory avant la lettre. Yet a closer reading suggests that the brain functions not as a two-way go-between but as a one-way valve. When aesthetic pleasure arises in the body it affects the brain, conceived as a physical organ, not the soul. When aesthetic pleasure arises in the soul (for example, in the "representation of a spiritual perfection") it has a material effect on the brain-arranging "the fibers of the brain into an appropriate tone" - which then, in turn, has a material effect on the body. By holding on to a Cartesian distinction between brain and soul, then, Theocles manages to concede a great deal to the materialist account of aesthetic pleasure while nonetheless defending his primary notion of the transcendental soul. Yet again, though, Theocles's hypothesis, though ingenious, is not entirely convincing. Even before he read Burke, then, Mendelssohn was struggling with materialist accounts of aesthetic pleasure that he sought to accommodate and contain but that strained his own theory to the limit.

One of the limitations of "On Sentiments" is that it treats aesthetics almost exclusively in terms of beauty. Even here, as we have seen, Theocles is not able entirely to accommodate or neutralize Euphranor's Epicurean account of the beautiful and its negative potential. Yet there are moments in the dialogue when intimations of the sublime threaten Theocles's position even more radically. In the crucial eighth letter, for example, Euphranor challenges Theocles's general claim that "the basis of all pleasure is to be found either in perfection or in beauty" by pointing out that human beings "often . . take pleasure in what ought to arouse their sorrow." 62 Although the term is not used in "On Sentiments," Euphranor's examples indicate that he is talking about the sublime:

That rocky cliff which juts outward above the river rushing by presents a grisly sight. The vertigo-inducing heights, the deceptive fear of falling, and the plunge to the depths below that those pieces of rock hanging over the edge appear to threaten-all this often forces us to avert our agitated gaze from it. Yet, after a quick recovery, we direct our eyes again to this fearful object. The grisly sight pleases. Whence this peculiar satisfaction? ${ }^{63}$

Theocles himself, Euphranor reminds him, takes pleasure in the painting of a ship being destroyed in a storm in which a "towering wave" is about to overwhelm 
the struggling sailors. Euphranor stresses that this "is no longer the beautiful nature; no, it is the fearful, the terrifying nature. And you find it enjoyable? . . . How does this rhyme with your theory?" 64 Theocles fails to answer Euphranor's questions, and they are only returned to in the conclusion, where the "editor" summarizes Theocles's later "off the record" attempt to account for this apparent contradiction between aesthetic experience and aesthetic theory. First, we are told that Euphranor presented his challenge to Theocles because he had been seduced by Jean Baptiste Du Bos's Réflexions sur la poésie et sur la peinture (1719), which attempted to prove, Mendelssohn's "editor" tells us, that "souls long merely to be moved, even if they have to be moved by unpleasant images." ${ }^{\prime 65}$ But although both Euphranor and Theocles are said to reject this theory, they still need to account for the fact that human beings do enjoy "painfully pleasant sentiments." 66 In seeking to explain this according to his own aesthetic theory, Theocles, in the editor's summary, focuses entirely on the pleasure human beings sometimes take in witnessing the suffering of other human beings (in reality or in representation). He therefore fails to answer Euphranor's question about why terrifying objects in nature yield a peculiar satisfaction. In other words, it appears that although Mendelssohn recognizes the aesthetic power of the sublime, he is not yet able to incorporate it within his aesthetic theory. The question of whence this peculiar satisfaction remains largely unanswered in "On Sentiments."

When Lessing sent his copy of the first edition of Burke's Enquiry to Mendelssohn in April 1758, then, Mendelssohn had already begun to work out an aesthetic theory whose assumptions and aims were distinctively non-Burkean. At the same time, it is clear that Mendelssohn was concerned with many of the same questions that Burke deals with in the Enquiry and that his non-Burkean answers to those questions were derived through unsatisfactory responses to internal and external voices that spoke with a distinctly Burkean accent. A major problem is the way Mendelssohn avoids any sustained discussion of the sublime. Three years later, however, Mendelssohn approached the sublime head on in his "Betrachtungen über das Erhabene und das Naive in den schönen Wissenschaften" (1758), published in Volume 2, Part 2 of the Bibliothek. In this essay, Mendelssohn tries to account for the sublime (das Erhabene) in terms of the metaphysical principles that we have examined. Yet despite this theoretical divergence from Burke, I want to suggest that Mendelssohn's explicit engagement with the sublime was at least partly triggered by his encounter with Burke's Enquiry. Although there is no mention of Burke in "On the Sublime and Naive in the Fine Sciences" - even in the version that Mendelssohn revised for his Philosophische Schriften of 1761-Mendelssohn's discussion of the sublime in this essay is often strikingly reminiscent of Burke's. In fact, some of his examples of the sublime are precisely the same as those he would soon focus on in his review of the Enquiry. For this reason, I suggest, contra Beck, that Mendelssohn must have read Burke's Enquiry before or during the process of writing "On the Sublime." 67 To establish this, I will examine Mendelssohn's review 
of the Enquiry before looking at "On the Sublime and Naive," even though the former was published a few months after the latter.

\section{MENDELSSOHN'S REVIEW OF BURKE'S ENQUIRY}

Mendelssohn's anonymous 1758 review of Burke's Enquiry appeared in Volume 3, Part 2 of the Bibliothek-two issues later than "On the Sublime and Naive." ${ }^{68}$ In his introduction, Mendelssohn makes a remark about the relationship between English empiricism and German rationalist theory that generalizes what Lessing had said of the Enquiry in the private letter already quoted (Mendelssohn assumes that the anonymous author was English):

Our neighbors, and especially the English, go ahead of us with philosophical observations of Nature; we follow them closely with our rational conclusions; and if it continues, that our neighbors observe and we explain, we can hope, in time, to arrive at a perfect theory of the sentiments, whose benefits in the fine sciences will certainly not be small. ${ }^{69}$

But such progress can come about "only if the philosopher [der Weltweise] does not allow himself to be repelled by the most peculiar-looking observations, and does not despair of the possibility of explaining them on psychological grounds." ${ }^{70}$ As for the Enquiry itself, Mendelssohn is guardedly enthusiastic about Burke's original and suggestive observations about aesthetic experience but scathing about his theoretical system, whose inadequacies are due to Burke's failure to study German philosophy:

The present text contains so many new and unusual remarks, that they can tempt an insufficiently attentive philosopher to doubt their truth or abandon his [the author's] system. The anonymous author also seeks to tear up all known systems. But it appears to us that his philosophy is in many places not grounded enough and that he has not correctly examined the systems that he believes he has refuted. It would be wished that the English would study our philosophy as diligently as we consult their observations. ${ }^{71}$

Despite these reservations, Mendelssohn's review consists of a detailed account of Burke's arguments and observations that reveals an accurate and often sympathetic understanding of the Enquiry. Consider, for example, Mendelssohn's summary of the Enquiry's discussion (in Part 2, Sections 8-9) of uniformity of succession in art:

Uniformity of succession produces the idea of infinity. Close succession allows the imagination to continue forwards, and uniformity allows it to do so without limits or interruption. 
Through the application of this principle in architecture the author assesses the construction of the old heathen temple, which generally appears from the outside as a longish oblong with uniform rows of columns on either side, and prefers it to the newer kind that gives churches the form of the cross. ${ }^{72}$

Later, Mendelssohn rehearses Burke's observations, in Part 2, Section 14 of the Enquiry, concerning the potential of sudden or excessive light to produce the sublime. ${ }^{73}$ As we will see, Mendelssohn uses precisely the same examples in "On the Sublime and Naive" published earlier the same year.

The section of the Enquiry that Mendelssohn finds most philosophically stimulating is the fourth part, in which Burke seeks to locate the efficient causes of aesthetic affect in the effects of objects on the human body's sensory organs. This is curious because, of all the arguments in the Enquiry, it is the one that is most removed from Mendelssohn's own grounding of aesthetic affect in the $a$ priori, transcendental powers of the soul. Yet Mendelssohn's interest in this section of the Enquiry may be accounted for by the way it develops a physiological analysis of aesthetic affect that is strikingly similar to that which he gives some ground to in "On Sentiments." The only parts of the Enquiry that Mendelssohn objects to are the non-representational theory of language in Part 5-which fundamentally diverges from his own theory of poetic language $\mathrm{e}^{74}$-and the attempt in the early sections of Part 3 to dissociate the beautiful from perfection and virtue. Given that Mendelssohn's aesthetic theory, prior to his encounter with Burke, had been devoted to defending a conception of the beautiful that linked it both to perfection and to virtue, it is not surprising that he suggests that Burke's philosophy "appears to us here to be the least grounded."75

One of the most notable things about Mendelssohn's review of the Enquiry is that he appears to accept Burke's observations on the sublime without criticism. This lack of criticism might be explained by Mendelssohn's announcement: "Our intention is not to take on this work. We leave it with pleasure to another pen, which will soon produce a German translation of this fine text, with notes and supplements, as advertised in the trade fair catalogue."76 Mendelssohn appears to be referring here to the never-to-be-completed translation that Lessing was supposedly working on and that had been advertised in the Ostermeßkatalog of $1758 .{ }^{77}$ In effect, Mendelssohn is passing the buck back to Lessing-indicating, perhaps, that Mendelssohn is not yet able to develop a critical perspective on the Burkean sublime.

\section{"ON THE SUBLIME AND NAIVE IN THE FINE SCIENCES"}

Although Mendelssohn's "On the Sublime and Naive" was published some months prior to his review of Burke's Enquiry, and although there is no mention of Burke in the text, there are indications that it can be read as a response to the Burkean sublime. Even though he has put the dialogue form to one side, then, 
Mendelssohn continues to develop his aesthetic theory in dialogue with other texts. For Dahlstrom, one of the essay's important features is that it anticipates Kant's distinction between the mathematic and dynamic sublime by differentiating between "the immensity of extended and of non-extended ('intensive') magnitudes." ${ }^{\prime 78}$ Yet although the distinction between these two kinds of magnitude does shape the whole argument of "On the Sublime and Naive," I would like to suggest that Mendelssohn is not looking forward to Kant but trying to rethink the sublime in ways that might neutralize some of the most challenging aspects of Burke's Enquiry. While Burke's examples of the sublime include both extensive and intensive magnitudes (although he doesn't use these terms), the bulk of the first edition of the Enquiry focuses on extensive magnitudevastness, infinity, and so on. Of infinity, for example, he says that it "has a tendency to fill the mind with that sort of delightful horror, which is the most genuine effect, and truest test of the sublime. ${ }^{\prime 79}$ For Burke, all experiences of the sublime are triggered by what Mendelssohn would call the negative qualities of the object: "whatever is fitted in any sort to excite the ideas of pain, and danger, that is to say, whatever is in any sort terrible, or is conversant about terrible objects, or operates in a manner analogous to terror, is a source of the sublime." 80 One of the consequences of Burke's account of the sublime, and this applies especially to the sensuously immense, is that it makes it difficult to maintain any link between aesthetics and ethics. ${ }^{81}$ Mendelssohn, I want to argue, introduces a clear distinction between extensive and intensive magnitudes in order to differentiate between the Burkean sublime and a genuine sublime based on the positive qualities of perfect objects that exhibit intensive magnitude. For one of the notable features of "On the Sublime and Naive" is that Mendelssohn never states that extensive magnitude is a source of the sublime.

Mendelssohn begins with a discussion of the aesthetic impact of natural objects whose dimensions go beyond the boundaries that constitute (his theory of) the beautiful:

We have seen that what is genuinely beautiful has definite boundaries which it may not overstep. If the full dimensions of the object cannot be taken in by the senses all at once, then it ceases to be sensuously beautiful and becomes gigantic or enormous in extension. The sentiment that is then aroused is, to be sure, of a mixed nature. For well-educated minds, those used to order and symmetry, there is something repugnant about this, since the senses ultimately can perceive the boundaries, but cannot comprehend them and combine them into one idea without considerable difficulty.-If the boundaries of this extension are deferred further and further, then they ultimately disappear completely from the senses and, as a result, something sensuously immense emerges. The senses, which perceive things insofar as they are homogeneous, begin to ramble in an effort to comprehend the boundaries and end up losing themselves in what is immense. The result . . is initially a trembling or shudder that comes over us and then something similar to dizziness that 
often forces us to divert our eyes from the object. The unfathomable world of the sea, a far-reaching plain, the innumerable legions of stars, every height and depth that is beyond the reach of the eye, eternity, and other such objects of nature which appear immeasurable to the senses, arouse the sort of sentiment which in several instances ... is quite alluring, but in many cases is upsetting. ${ }^{82}$

Although this passage recalls Euphranor's account of those natural objects that produce mixed sentiments, and also echoes what Burke says about the sublime, Mendelssohn does not include the sensuously immense under the sublime. While the sensuously immense produces mixed sentiments, there is something "repugnant" about the way it breaks with order and symmetry and exceeds the bounds of the beautiful. More importantly, it has a disturbing, disorientating effect on the self or subject that tries to comprehend such an object and resists the attempt of the senses to combine the object into one idea. While, for Burke, these effects are characteristic of the sublime, they threaten the transcendental subject that is the basis of Mendelssohn's whole philosophical outlook.

Mendelssohn nonetheless recognizes that artists and poets attempt to represent the sensuously immense because it produces pleasant as well as unpleasant sensations. Again, though, he does not use the term sublime. Instead, perhaps echoing Addison, he says that "the imitation of the sensuously immense in art is named straightforwardly 'the grand or the enormous' [das Große]." ${ }^{33}$ Mendelssohn then stresses, as Burke does, that art's inherent limitations mean that it can only produce the illusion of immensity or infinity-what Burke calls "the artificial infinite." ${ }^{\prime 84}$ Furthermore, Mendelssohn's examples of the way art does this echo Burke's discussion in the Enquiry of the sublime effects of succession and uniformity in music and architecture (Mendelssohn refers to "a straight corridor of pillars") and the deployment in art of excessive light and darkness. ${ }^{85}$ The fact that Mendelssohn would soon discuss the same principles and examples in his forthcoming review of the Enquiry suggests that "On the Sublime and Naive" makes use of Burke's ideas without acknowledging the fact. At the same time, however, by quietly rejecting the notion that the sensuously immense, in reality or in imitation, is sublime, Mendelssohn is rejecting a large part of Burke's argument and a large portion of his examples.

Mendelssohn then goes on to distinguish between extended and non-extended magnitudes and their effects:

Just as there is an immensity of extended magnitude, . . . so there is an immensity of strength or unextended magnitude that has effects similar to the former. Power, genius, virtue have their unextended immensity that likewise arouses a spine-tingling sentiment but has the advantage of not ending, through tedious uniformity, in satiation and even disgust, as generally happens in the case of the extended immensity. ${ }^{86}$ 
Mendelssohn reserves the term "sublime" for the effect of intensive, non-extended magnitude, which is a quality of objects or beings or concepts that are perfect in themselves:

The term commonly applied to what is intensively enormous is "strength," and strength in perfection is designated "the sublime." In general, one could also say: each thing that is or appears immense as far as the degree of its perfection is concerned is called sublime. God is called "the most sublime being." A truth is said to be "sublime" if it concerns a quite perfect or complete entity such as God, the universe, the human soul and if it is of immense use to the human race or its discovery would require a great genius. ${ }^{87}$

Mendelssohn here reconnects the sublime with the good, the true, and the perfect. As a consequence, "the sentiment that [sublime objects] arouse is unmixed from the side of the object. This is why the soul indulges in them with such fervor." ${ }^{\prime 8}$ Yet although Mendelssohn maintains the assumption that the sublime generates a mixed sentiment, he is rather vague about where the negative element comes from.

In "On Sentiments" Mendelssohn had begun to develop a theory that supposedly explained how the soul could experience aesthetic pleasure when confronted with the kind of sensuously immense objects that violated the constraints of Baumgarten's category of the beautiful. He attempted to bring the sublime under the framework of Leibniz-Wolffian metaphysical theory by abandoning the assumption that the object needs to be perfect and relocating that perfection in the perceiving subject. In the above passage, however, Mendelssohn claims that the sublime is produced by the subject's encounter with a perfect object that exhibits intensive magnitude. Mendelssohn, then, develops a series of different, and sometimes incompatible, accounts of the sublime in an ongoing attempt to reconcile the sublime with Leibniz-Wolffian metaphysics. This very fact bears witness both to the problems he had with this aesthetic category and to the intellectual creativity with which he responded to those problems. The new theory of the sublime that emerges in "On the Sublime and the Naive" serves as a temporary holding device against Burke's Enquiry and indicates that Mendelssohn has not yet been able to reconcile the Burkean sublime with the metaphysical aesthetic theory developed in earlier essays. Yet the new theory is clearly problematic in that it excludes a large portion of those natural objects that both Euphranor and Burke saw as sources of the sublime. The question of whence the peculiar satisfaction of natural objects such as vertigo-inducing heights continues to trouble Mendelssohn. 


\section{"RHAPSODY, OR ADDITIONS TO THE LETTERS ON SENTIMENTS"}

"Rhapsody, or Additions to the Letters on Sentiments" was first published in Mendelssohn's Philosophische Schriften of 1761. It is primarily concerned with re-examining the problem of mixed sentiments from a fresh perspective suggested by Lessing:

On February 2, 1757, Lessing had written: "Surely we both agree, dearest friend, that all passions are either vehement desires or vehement detestations. We also agree that through every vehement desire or detestation we are made conscious of a higher degree of our reality. Hence all passions, even the most unpleasant ones, are pleasant as passions." On March 2, 1757, Mendelssohn had replied: "You are perfectly right. The ability to love perfections and to detest imperfections is a reality and, therefore, a perfection. Exercising it is, hence, bound to afford us pleasure. What a pity that this fine observation was unknown to me when I wrote my letters On the Sentiments!" 89

Yet if Mendelssohn therefore admits in "Rhapsody" that "it was not right for me to criticize Du Bos for saying that the soul longs merely to be moved, even [if] it is to be moved by unpleasant representations," we will see that he transposes Du Bos's observation into his own philosophical system. ${ }^{90}$ But Mendelssohn also admits that he is revisiting the question of the mixed sentiments of the sublime because of the impact of Burke's Enquiry:

When I wrote the "Letters on sentiments" . . I had, to be sure, a flimsy concept of the nature of mixed sentiments. But I only saw a flickering of the astonishing and myriad effects of them until I had the opportunity to read the splendid English work on the sublime and the beautiful for the Library of Fine Sciences. The author of the work is a keen observer of nature. He heaps observation on top of observation, each of which is as basic as it is discerning. Yet, whenever it comes down to explaining these observations on the basis of the nature of the soul, his shortcomings become apparent. One sees that he was unacquainted with the psychology developed by German philosophers. Mere experience was not sufficient for him to be able [to] see these profound doctrines in connection with one another. The basic principle that intuitive knowledge of perfection is gratifying was regarded by him as a mere hypothesis and the slightest experience which seemed to contradict the hypothesis was reason enough for him to reject it. However, anyone convinced that this basic principle of sentiments is no hypothesis, but rather an established and irrefutable truth is not going to allow experience to lead him astray, however much it may appear to present the opposite. Such a person considers the matter further and finds the most precise kinship between reason and experience, something that frequently is to be found only with difficulty, though it is always at hand. ${ }^{91}$ 
In this passage Mendelssohn reiterates the response to the Enquiry presented in his review, simultaneously celebrating Burke's empirical observations and criticizing his failure to reconcile experience with Leibniz-Wolffian rationalist psychology. Yet this criticism of Burke can also be read as an extraordinarily frank admission of the anxiety that the Enquiry has aroused in Mendelssohn, who is in effect announcing that he is determined to hold fast to his own a priori, rationalist theory however much Burke's empirical observations might appear to challenge it.

"Rhapsody" begins, in fact, by noting the way actual experience serves to qualify the basic assumption in "On Sentiments," derived from Maupertuis's Essai de philosophie morale (1755), that aesthetic sentiments can be neatly divided into pleasant ones that we wish to have and unpleasant ones that we wish to avoid. The fact that we sometimes derive pleasure from the representation of unpleasant experiences or objects, such as the Lisbon earthquake of 1755, forces Mendelssohn to seek out ways of reconciling such mixed sentiments with his modification of the Leibniz-Wolffian account of the soul. In effect, he has returned to the problem of the negative sublime that he had side-stepped in "On the Sublime and Naive." One of the moves he makes, under Lessing's influence, is to rethink the relation between subject and object in aesthetic experience. In the case of the beautiful, subjective and objective correspond: the beautiful object is perfect and hence pleasurable, and the soul's representation of it is also, necessarily, perfect and hence pleasurable. The sublime, by contrast, is produced when a perfect subject encounters an imperfect object, generating a mixed sentiment comprised of repugnance towards the object and pleasure from the soul's capacity to represent it:

This satisfaction or dissatisfaction refers ... to the object; they apply only to the thing that possesses the affirmative or the negative features. We feel gratified or not by the organization and constitution of the thing after we perceive realities or deficiencies in it. In relation to the thinking subject, the soul, on the other hand, perceiving and cognizing the features as well as testifying to enjoying them or not constitutes some sort of content [Sachliches] that is posited in the soul, an affirmative determination of the soul. Hence, every representation, at least in relation to the subject, as an affirmative predicate of the thinking entity, must have something about it that we like. For even the picture of a deficiency in the object, just like the expression of discontent with it, are not deficiencies on the part of the thinking entity, but rather affirmative and material determinations of it. ${ }^{92}$

This move is yet another attempt to theorize the mixed sentiments of the sublime without relinquishing the Leibniz-Wolffian metaphysics of perfection: whereas Baumgarten accounted for aesthetic pleasure through the clear but indistinct representation of a perfect object, Mendelssohn now locates that per- 
fection in the soul's power of representation regardless of whether or not the object itself is perfect.

Mendelssohn's new explanation of how the perfect soul can derive aesthetic pleasure from its encounter with imperfect, even threatening, objects leads him to stress that "we must indeed take care not to mix or confuse these two relations, the objective and the subjective, with one another." 93 Yet one of the disturbing things about the sublime, as Burke notes, is that the sublime object has a tendency to press too close and thereby destroy all possibility of deriving pleasure from it: "When danger or pain press too nearly, they are incapable of giving any delight, and are simply terrible; but at certain distances, and with certain modifications, they may be, and they are delightful, as we every day experience. ${ }^{\prime 94}$ For Mendelssohn, what is terrifying about the too near approach of the terrifying object is that it threatens to annihilate the crucial distinction between subject and object:

If the object gets too close to us, if we regard it as a part of us or even as ourselves, the pleasant character of the representation completely disappears, and the relation to the subject immediately becomes an unpleasant relation to us since here subject and object collapse, as it were, into one another. . . We can rightly say of this sort of representation that we would prefer not to have it than to have it. For every impulse of the soul sets itself against this representation and seeks to get rid of it..$^{95}$

Mendelssohn's attempt to readmit the negative Burkean sublime, which turns on pain and danger, has quickly become problematic. For Burke, the attempt to overcome the collapse of subject and object—-to remove difficulties or overcome pain or danger — can itself be productive of sublime experience. ${ }^{96}$ While Mendelssohn almost says this at one point, the sublime's tendency to collapse the distinction between subject and object indicates one of the ways that it threatens the metaphysical grounds of his whole aesthetic theory.

One way in which Mendelssohn tries to preserve his theory is to differentiate once more between what we might call the negative and the positive sublime. The negative sublime is generated by objects that are threatening, painful, or evil, and that press too close. But what is striking about "Rhapsody," in comparison with "On the Sublime and Naive," is that the positive sublime may be generated by both extensive and intensive magnitudes. As a consequence, a large range of Burke's examples of the sublime are readmitted into Mendelssohn's definition of the sublime. Indeed, the following passage from "Rhapsody" rewrites what Mendelssohn says in "On the Sublime and Naive" in ways that make it sound like Burke:

An immense object that we can contemplate as a whole but cannot comprehend ... arouses a mixed sentiment of gratification and its opposite, a sentiment which ini- 
tially sets off a trembling sensation and, if we continue to contemplate it, a kind of dizziness. This immenseness may consist in an extended or unextended, constant or variable magnitude [Größe]; but the sentiment in each case is the same. The unfathomable world of the sea, a far-reaching plain, the innumerable legions of stars, the eternity of time, every height and depth that exhausts us, a great genius, great virtues that we admire but cannot attain; who can look upon these things without trembling? Who can continue to feast his eyes upon them without experiencing a pleasant sort of dizziness? This sentiment is composed of gratification and its opposite. The magnitude of the object affords us gratification, but our inability to comprehend its boundaries adds a certain degree of bitterness to this gratification, making it all the more alluring. ${ }^{97}$

This passage mixes up examples of extended and unextended magnitude and suggests that they produce the same sublime effect. Yet the sources of the positive and negative aesthetic effects that make up the sublime are precisely the reverse of what Mendelssohn suggests earlier in the essay. Here, the "gratification" comes from the magnitude of the object, whether extended or intensive, and both kinds of magnitude are now compatible with perfectionMendelssohn goes on to say that "the immensity of the structure of the world, the magnitude of an amazing genius or of sublime virtues are as differentiated as they are enormous, as perfect as they are differentiated." 98 The negative element of the aesthetic response, by contrast, is now located in the subject since it comes from the soul's experience of its inability to produce an adequate representation of the perfect immense object. Although this new account of the sublime might have been quite fruitful, it would appear to undermine Mendelssohn's a priori theoretical assumption that aesthetic pleasure is derived from the soul's transcendental power of producing perfect representations of objects (whether perfect or imperfect). On the one hand, it is possible to admire the sheer variety of the creative solutions that Mendelssohn generates to account for the mixed sentiments of the sublime. On the other hand, it would seem that Mendelssohn's attempt to accommodate the Burkean sublime to his own version of the Leibniz-Wolffian metaphysical system has led his aesthetic theory into radical incoherence.

It is therefore significant that it is precisely at this point in the essay that Mendelssohn inserts the paragraph, examined above, in which he both acknowledges Burke's impact on his thinking about mixed sentiments and insists that Burke's empirical observations will not force him to relinquish his commitment to the rationalist metaphysics of perfection. That he has actually reached an impasse in his engagement with Burke is indicated by the fact that Mendelssohn then seeks to relinquish the responsibility of reconciling the Enquiry with German metaphysical psychology. Just as Lessing had initially passed the Enquiry to Mendelssohn as the person most fitted to use its materials for higher ends, so Mendelssohn once again suggests that Lessing is the man for the job: 
In no way do I flatter myself with having provided the psychological basis for all the experiences noted by the Englishman. Our sentiments have such depths that poking my eye in their direction is all too fatuous. I wish rather, by my effort here, to have encouraged a philosophical mind to undertake this worthwhile investigation. My friend still owes the world a translation that he promised to give of the English work along with emendations and notes. If only he would fulfill my wish!99

This apparent admission of theoretical failure might be no more than conventional authorial modesty or a public attempt to flatter Lessing into completing his translation of the Enquiry. Yet the dynamics of Mendelssohn's essay suggest that his confrontation with Burke has been more troubling to his own aesthetic theory than he would wish and that he now seeks to purge the essay of Burke's disturbing presence. After this point in the essay Mendelssohn reverts to the theoretical positions he had established before reading Burke, withdrawing from the problem of the mixed sentiments of the sublime and reiterating the aesthetic theory of the beautiful maintained by Theocles in "On Sentiments." Mendelssohn stresses once more the ethical problems raised by what he calls "the refined Epicureanism" of British and French materialist philosophers who "place the highest good . . . in the pleasant sentiment instead of analyzing it further, as they should, and looking for it ... with modern philosophers, in the original drive for perfection."100 Although British philosophers such as Shaftesbury and Hutcheson had linked aesthetics and ethics by grounding them in pleasant feelings, such claims, while they are laudable as far as practical ethics goes, ultimately pose a threat to the soul's freedom. By contrast, "our philosophers" (i.e., Leibniz and Wolff) "prove irrefutably . . . that the power of our soul, of each spirit generally, is originally orientated to the good and perfect, and that the choice of a spirit which is free could not possibly have anything but perfection as its sufficient reason." ${ }^{101}$ In face of the continuing threat to German philosophy posed by French and British materialism, then, Mendelssohn seems reduced merely to reiterating the metaphysics of perfection as a kind of antidote. Mendelssohn's deepest ambivalence is towards Burke's Enquiry. Although Mendelssohn made pioneering efforts to accommodate Burke's account of the sublime into his own aesthetic system, in the end he is forced to expel it not only because of Burke's materialist empiricism but also because Burke's aesthetics is built on a fundamental opposition between aesthetic affect and moral perfection, seems to compromise the soul's supposedly original freedom, and challenges the metaphysical grounds of Mendelssohn's whole philosophy.

Mendelssohn's "Rhapsody" brought to a close the series of writings on aesthetics that he began in 1755. Mendelssohn's later writings brought him success and fame, but they struggled in vain against anti-Leibnizian philosophical tendencies. In the end, however, Mendelssohn came to realize that the death-blow to the Leibniz-Wolffian system came not directly from British empiricism but 
from Kant's absorption of it. ${ }^{102}$ As David Sorkin notes, "after the publication of Kant's Critique of Pure Reason (1781) Mendelssohn was fully aware that his Wolffianism was under siege: he confessed that he ceased to be current with philosophical developments and, in a phrase that has since become famous, dubbed his erstwhile competitor 'the all-destroying Kant'."103

Mendelssohn's struggle to cope with the Burkean sublime can therefore be located within the context of a much larger internal struggle in German philosophy. It also set a pattern for the responses of many German aesthetic theorists to the Enquiry. For Kant, of course, the distinction between the beautiful and the sublime was a shaping paradigm of his thinking about aesthetics from the Beobachtungen über das Gefühl des Schönen und Erhabenen (1764) to the Critik der Urteilskraft $(1790,1793)$. Indeed, in the latter, Kant praises Burke's physiological-cum-psychological investigations of the distinction between the sublime and the beautiful, which he read in Christian Garve's translation of 1773, as "analyses of the phenomena of our mind" that are "extremely fine" - though he also stresses that Burke's empirical observations can only be a first step towards a transcendental theory of aesthetics. ${ }^{104}$ But Kant's enthusiasm for the Burkean sublime was relatively unusual in late eighteenth-century Germany. As Strube notes, Burke's distinction between the sublime and the beautiful

is not always praised as a "fine observation," but also often dammed as an inadmissible differentiation. Against Burke, Herder already maintains: “. . . the sublime and beautiful are not opposites, but stem and branches of one tree;" and Herder regrets that Lessing did not find time for commentary on Burke, because "certainly he would have sought and found unity between both principles in our nature." The attempt to overcome the dualism of the beautiful and the sublime is repeatedly undertaken by idealist German aestheticians, such as Schelling and Solger; and from this idealist standpoint Burke was reproached for having "first torn the concepts of the beautiful and the sublime from one another" and thereby introducing a disastrous development in aesthetics. ${ }^{105}$

The fact that German aesthetic theorists-except for Kant-repeatedly attempted to overcome the dualism of the beautiful and the sublime points precisely to the difficulty they had in "correcting" this "disastrous development in aesthetics." In regretting that Lessing did not find time for a critique of Burke that "would have sought and found unity between both principles in our nature," Herder re-enacts Mendelssohn's symptomatic palming off of the problem onto Lessing. Yet there is no indication in Lessing's responses to Burke that he was any more capable than Herder or Mendelssohn of dealing with Burke's "disastrous" development. The attempt to reduce Burke's Enquiry to a set of empirical observations in need of theoretical explanation by German philosophy was not cultural arrogance but indicative of the crisis that the Burkean sublime had generated in German aesthetic theory. 


\section{NOTES}

This article is dedicated to the memory of Wolfgang Iser (1926-2007), who heard an early version of it at a Conference on the Reception of Edmund Burke (University of London Senate House, 2004) and gave me encouragement when I needed it most.

1. Frederick C. Beiser, The Fate of Reason: German Philosophy from Kant to Fichte (Cambridge, Mass., 1987), 92.

2. For the authoritative English-language study of Mendelssohn's life and work, see Alexander Altmann, Moses Mendelssohn: A Biographical Study (Tuscaloosa, 1973).

3. See Allan Arkush, Moses Mendelssohn and the Enlightenment (New York, 1994); and David Sorkin, Moses Mendelssohn and the Religious Enlightenment (Berkeley, 1996). For a useful discussion of Leibniz and Wolff that questions the legitimacy of talking about a "Leibniz-Wolffian" philosophical system, see Lewis White Beck, Early German Philosophy: Kant and His Predecessors (Cambridge, Mass., 1969), 196-275 (esp. 256-75).

4. Beiser, 93-94.

5. See Moses Mendelssohn, "Dialogues," Moses Mendelssohn: Philosophical Writings, trans. and ed. Daniel O. Dahlstrom (Cambridge, 1997), 96-129. Unless otherwise noted, all quotations from Mendelssohn's aesthetic writings are taken from this edition; this edition is based on the second edition of Philosophische Schriften, published in 1771, in which Mendelssohn made a number of revisions to the original essays (for Mendelssohn's account of these revisions, see "Preface," 4-5).

6. Beck, 316.

7. Altmann, Moses Mendelssohn, 32. For a discussion of "the popular philosophy of the literary periodicals and coffeehouses" of Berlin in the third quarter of the eighteenth century, see Beck, 319-24. On Mendelssohn's links with the "popular philosophers," see Johan Van Der Zande, "In the Image of Cicero: German Philosophy Between Wolff and Kant," Journal of the History of Ideas 56, no. 3 (July 1995): 419-42, 421; and Hans Joachim Schneider, Moses Mendelssohns Anthropologie und Ästhetik: Zum Begriff der Popularphilosophie (Westfalia, 1970).

8. Robert E. Norton, The Beautiful Soul: Aesthetic Morality in the Eighteenth Century (Ithaca, 1995), 89. For an essay on Mendelssohn's general familiarity with English authors, see George John ten Hoor, "Moses Mendelssohn's Relation to English Poetry," PMLA 46, no. 4 (December 1931): 1137-65.

9. Norton, The Beautiful Soul, 89.

10. Paul Guyer, Kant and the Experience of Freedom: Essays on Aesthetics and Morality (Cambridge, 1993), 132. Also see Kai Hammermeister, The German Aesthetic Tradition (Cambridge, 2002), 3-20.

11. Beck, 326. For the impact of Mendelssohn's aesthetic writings on the development of eighteenth-century German aesthetics, see Guyer, 147-60; Hermann Cohen, Kant's Begrïndung der Aesthetik (Berlin, 1889); and Armand Nivelle, Kunst- und Dichtungstheorien zwischen Aufklärung und Klassik, 2nd ed. (Berlin, 1971). Despite their influence, Mendelssohn's aesthetic writings are often ignored. Mendelssohn is not included in H. B. Nisbet, ed., German Aesthetics and Literary Criticism: Wincklemann, Lessing, Hamann, Herder, Schiller, Goethe (Cambridge, 1985), and only features in three footnotes and an epigraph in J. M. Bernstein, ed., Classic and Romantic German Aesthetics (Cambridge, 2003).

12. The most useful account of this tradition, which began with Plato, occurs in Norton, The Beautiful Soul.

13. While Altmann pays significant attention to Mendelssohn's aesthetics, Edmund Burke is mentioned only twice in passing (see Moses Mendelssohn, 31 and 126). An exception is Ludwig Goldstein, Moses Mendelssohn und die Deutsche Asthetik (Königsberg, 1904), 148-53, which discusses Mendelssohn's "Rhapsody, Or Additions to the Letters on Sentiments" in terms of Mendelssohn's relationship to Burke. Beck claims that while Mendelssohn's aesthetic writings "show the influence of Shaftesbury and some resem- 
blances to Burke, he had in fact formulated his theory of the sublime before he had read Burke" (326).

14. For a substantial collection of essays on Burke's general reception in Europe, see Peter Jones and Martin Fitzpatrick, eds., The Reception of Edmund Burke in Europe (London, forthcoming).

15. Samuel H. Monk's The Sublime: A Study of Critical Theories in XVII-Century England (Ann Arbor, 1960) assumes a teleological continuity between eighteenth-century British aesthetics and the German aesthetic tradition culminating in Kant; Peter De Bolla argues for radical discontinuity (The Discourse of the Sublime: History, Aesthetics and the Subject, [Oxford, 1989], 289-93).

16. See Piero Giordanetti, "Zur Rezeption von Edmund Burkes Schrift 'A Philosophical Enquiry into the Origin of our Ideas of the Sublime and Beautiful' bei Hamann und Kant," Johann Georg Hamann und England: Hamann und die englischsprachige Aufklärung, ed. Bernhard Gajek (Frankfurt am Main, 1999), 295-303. (I am grateful to Dr. Tomáš Hlobil for pointing out this reference.)

17. Werner Strube, "Einleitung" to Edmund Burke, Philosophische Untersuchung über den Ursprung unserer Ideen vom Erhabenen und Schönen, ed. Strube and trans. Friedrich Bassenge (Hamburg, 1989), 24-25. (Unless otherwise noted, all translations from German are my own. I would like to thank Dr. Uwe Töllner and Dr. Michael Kerth for their invaluable help with these translations.)

18. Strube, 25-26.

19. For the Bibliothek der schönen Wissenschaften und der freyen Künste, see "Retrospektive Digitalisierung wissenschaftlicher Rezensionsorgane und Literaturzeitschriften des 18. und 19. Jahrhunderts aus dem deutschen Sprachraum," an online digital archive presented by Universität Bielefeld Bibliothek at http://www.ub.uni-bielefeld.de/diglib/ aufkl/bibschoewiss/.

20. See Lessing to Nicholai, 25 November 1757, in Briefe von und an Lessing 1743-1770, ed. Helmuth Kiesel et al., vol. 11.1 of Gotthold Ephraim Lessing: Werke und Briefe, ed. Wilfried Barner et al. (Frankfurt am Main, 1987), 261.

21. See Lessing to Mendelssohn, 21 January 1758, in Briefe, 268.

22. Lessing to Mendelssohn, 18 February 1758, in Briefe, 275-76.

23. Strube, 24.

24. Lessing to Mendelssohn, 2 April 1758, in Briefe, 288.

25. The first published German translation of the Enquiry was Christian Garve's anonymous Philsophische Untersuchungen über dem Ursprung unserer Begriffe vom Schönen und Erhabenen (Riga, 1773).

26. See Lessing, "Bemerkungen über Burkes Philosophische Untersuchungen über den Ursprung unserer Begriffe vom Erhabenen und Schönen," Gotthold Ephraim Lessing: Werke 1758-1759, ed. Gunter E. Grimm, vol. 4 of Lessing: Werke und Briefe (Frankfurt am Main, 1997), 448-52; see also Grimm's editorial notes, 1040-49.

27. James T. Boulton, ed., "Editor's Introduction," A Philosophical Enquiry into the Origin of our Ideas of the Sublime and Beautiful, by Edmund Burke (Oxford, 1987), vii-xlviii, xlvii. See Lessing, Laocoön: An Essay on the Limits of Painting and Poetry, trans. and ed. Edward Allen McCormick (Baltimore, 1984).

28. For this view, see Hlobil, "Two Concepts of Language and Poetry: Edmund Burke and Moses Mendelssohn," The British Journal for the History of Philosophy 8, no. 3 (October 2000): 447-58.

29. For Mendelssohn's essays and reviews in the Bibliothek, see http://www.ub.unibielefeld.de/diglib/aufkl/bibschoewiss/; also see Mendelssohn, Rezensionsartikel in "Bibliothek der schönen Wissenschaften und der freyen Künste" (1756-1759), ed. Eva J. Engel, vol. 4 of Moses Mendelssohn: Gesammelte Schriften Jubiläumsausgabe, ed. Altmann et al. (Stuttgart, 1977).

30. Mendelssohn began his career with the Philosophical Dialogues of 1755 and secured 
his reputation as the "German Socrates" with Phädon oder über die Unsterblichkeit der Seele in drey Gesprächen (1767), a translation and rewriting of Plato's dialogue on the immortality of the soul. He discussed the nature of Socratic dialogue in his 1760 review of Jakob Wegelin's The Last Dialogues of Socrates and his Friends (see Altmann, Moses Mendelssohn, 142).

31. Anthony Ashley Cooper, Third Earl of Shaftesbury, "The Moralists, a Philosophical Rhapsody" [1709], Characteristics of Men, Manners, Opinions, Times [1711], ed. Lawrence E. Klein (Cambridge, 1999), 231-338, 327.

32. Mendelssohn, "On Sentiments," 7-95, 7.

33. Mendelssohn, "On Sentiments," 7.

34. Mendelssohn, "On Sentiments," 8.

35. For Burke, both the sublime and the beautiful are incompatible with reason. Regarding beauty, he says: "It is not by the force of long attention and enquiry that we find any object to be beautiful; beauty demands no assistance from our reasoning" (92). See Burke, 114-16 for his suggestion that the beautiful is epitomized by the erotic effect of women's bodies on men.

36. Mendelssohn, "On Sentiments," 12. For the relevant passages in Baumgarten, see Dahlstrom, "Introduction," ix-xxx, also see Hammermeister, 3-13. For a useful discussion of Baumgarten's aesthetics, see Beck, 283-86.

37. Beck, 326.

38. Altmann, Moses Mendelssohn, 45.

39. See Burke, 58-64 for his distinction between clear and aesthetically affecting ideas; see Burke, 110 for his claim, against a long-standing tradition, that "Perfection [is] not the cause of BEAUTY."

40. Mendelssohn, "On Sentiments," 13; and Beck 285-86 and 326.

41. Mendelssohn, "On Sentiments," 14.

42. Mendelssohn, "On Sentiments," 19.

43. Mendelssohn, "On Sentiments," 20.

44. Mendelssohn, "On Sentiments," 23-24. Mendelssohn's assumptions about the soul's original powers indicate a basic difference between British empiricism and the Leibniz-Wolffian school of rational metaphysics. Whereas, for Mendelssohn, ideas (or "representations") are products (or "determinations") of the soul, for British empiricism (in Locke and Hume for example) ideas are produced by impressions of objects conveyed to the mind via the senses.

45. See Burke, 149-60 for his attempt to locate the efficient causes of beauty in the effects of physical objects and phenomena on the human sensory system.

46. My use of the term "metaphysics of perfection" in reference to Mendelssohn's thought is influenced by Guyer, 149.

47. Mendelssohn, "On Sentiments," 27. Altmann suggests that this passage "has an unmistakable autobiographical ring" and decides that "the books that 'edified' [Mendelssohn] in his 'hours of loneliness' were above all, we may assume, Locke's Essay Concerning Human Understanding, Leibniz's Essais de Théodicée; and Wolff's Vernünfftige Gedanken" (Moses Mendelssohn, 27, 29).

48. Mendelssohn, "On Sentiments," 28.

49. Mendelssohn, "On Sentiments," 35-36.

50. Mendelssohn, "On Sentiments," 78.

51. Mendelssohn, "On Sentiments," 44.

52. Mendelssohn, "On Sentiments," 45.

53. "The philosophy that Palemon [Theocles] represents is, of course, of the Leibniz/ Wolffian type ... but it has a texture far richer than that" (Altmann, Moses Mendelssohn, 45). For the way Baumgarten's aesthetics enriched the Leibniz-Wolffian philosophy, see Beck, 283-86.

54. Mendelssohn, “On Sentiments," 45.

55. See Burke, 134-36, 149-50. 
56. Mendelssohn, "On Sentiments," 46.

57. Mendelssohn, "On Sentiments," 78-79.

58. Mendelssohn, "On Sentiments," 53.

59. Mendelssohn, "On Sentiments," 53.

60. Mendelssohn, "On Sentiments," 53.

61. Mendelssohn, "On Sentiments," 53.

62. Mendelssohn, "On Sentiments," 35, 36.

63. Mendelssohn, "On Sentiments," 36.

64. Mendelssohn, "On Sentiments," 37.

65. Mendelssohn, "On Sentiments," 71.

66. Mendelssohn, "On Sentiments," 72.

67. Beck asserts that "On the Sublime and Naive" was written before Mendelssohn had read Burke's Enquiry (329).

68. See Mendelssohn, "Philosophische Untersuchung des Ursprungs unserer Ideen vom Erhabenen und Schönen," Bibliothek der schönen Wissenschaften 3, no. 2 (1758): 290320, repr. in Rezensionsartikel, 216-36.

69. Mendelssohn, "Philosophische Untersuchung," 216.

70. Mendelssohn, "Philosophische Untersuchung," 216. According to Beck, the term Welt-Weisheit (world-wisdom) was introduced by the Leibniz-Wolffian school to distinguish philosophy from theology (Gottes-Gelahrtheit) (262).

71. Mendelssohn, "Philosophische Untersuchung," 216.

72. Mendelssohn, "Philosophische Untersuchung," 222.

73. Mendelssohn, "Philosophische Untersuchung," 223.

74. See Mendelssohn, "On the Main Principles of the Fine Arts and Sciences" [1757], 169-91. For the divergence between Burke's and Mendelssohn's theories of poetic language, see Hlobil.

75. Mendelssohn, "Philosophische Untersuchung," 224.

76. Mendelssohn, "Philosophische Untersuchung," 217.

77. See Grimm, 1044.

78. Dahlstrom, xxiii.

79. Burke, 73.

80. Burke, 39 .

81. In the second edition of the Enquiry, Burke included a new section on "Power" in which he suggests that our aesthetic response to the idea of God, the most perfect manifestation of intensive magnitude, is due entirely to our sense of God's power and excludes any consideration of "his wisdom, his justice, and his goodness" (68).

82. Mendelssohn, "On the Sublime and Naive in the Fine Sciences" [1761], 192-232, 192-93.

83. Mendelssohn, "On the Sublime and Naive," 193.

84. See Mendelssohn, "On the Sublime and Naive," 193; and Burke, 76, 139-40.

85. See Mendelssohn, "On the Sublime and Naive," 193-94, 196; and Burke, Part 2, Sections 9 and 10; Part 4, Sections 11-13; and Part 2, Sections 14-15.

86. Mendelssohn, "On the Sublime and Naive," 194.

87. Mendelssohn, "On the Sublime and Naive," 194-95.

88. Mendelssohn, "On the Sublime and Naive," 194.

89. Altmann, Moses Mendelssohn, 61.

90. Mendelssohn, "Rhapsody, or Additions to the Letters on Sentiments" [1761], 13168, 136-37.

91. Mendelssohn, "Rhapsody," 146-47.

92. Mendelssohn, "Rhapsody," 133.

93. Mendelssohn, "Rhapsody," 132.

94. Burke, 40.

95. Mendelssohn, “Rhapsody,” 134. 
96. For an account of how this works in Burke's Enquiry, see Tom Furniss, Edmund Burke's Aesthetic Ideology: Language, Gender and Political Economy in Revolution (Cambridge, 1993), 15-112.

97. Mendelssohn, "Rhapsody," 144-45.

98. Mendelssohn, "Rhapsody," 145.

99. Mendelssohn, "Rhapsody," 147.

100. Mendelssohn, "Rhapsody," 150.

101. Mendelssohn, "Rhapsody," 150.

102. For the "British" or Newtonian revolution in German philosophy and aesthetics, see Norton, Herder's Aesthetics and the European Enlightenment (Ithaca, 1991), 11-38.

103. Sorkin, 153.

104. Immanuel Kant, Critique of the Power of Judgment $(1790,1793)$, ed. Guyer and trans. Guyer and Eric Matthews (Cambridge, 2000), 158.

105. Strube, 26. Strube is quoting J. G. Herder, “Kalligone," Sämtliche Werke, vol. 22, ed. B. Suphan (Hildesheim, 1967), 240, 241; and A. Zeising, Aesthetische Forschungen (Frankfurt am Main, 1855), 18. 